\title{
Marriage, Kinship and Childcare in the Aftermath of AIDS: \\ Rethinking 'Orphanhood' in the South African Lowveld
}

Isak Niehaus

Anthropology Division, Brunel University London, United Kingdom.

E-Mail: isak.niehaus@brunel.ac.uk

In this article I consider the significance of marriage from the vantage point of children's affiliation to domestic units during the era of South Africa's AIDS pandemic. Drawing on multi-temporal fieldwork in Impalahoek, a village in the Bushbuckridge municipality of the South African Lowveld, I suggest that AIDS-related diseases and deaths have led to the further erosion of marriage, and to the greater absence of fathers in the lives of children. However, these changes have not precipitated a crisis in childcare. A survey of 22 households shows that orphaned children are generally cared for by related adults, such as matrikin and older female siblings. These arrangements are a product of a long history of improvisations, necessitated by experiences of oscillating labour migration. Moreover, they are facilitated by a diffusion of parental obligations, which is a central tenet of Northern Sotho and Shangaan models of kinship. I argue that in an economy of high unemployment and dependence upon state instituted social security systems, marriage does not appear to be decisive to children's welfare.

Keywords: marriage, kinship, childcare, orphans, social grants, HIV/AIDS, Bushbuckridge, South Africa. 
According to Leach (1982) anthropologists have thought about marriage in two contrasting ways. Most scholars conceptualise marriage as a union that establishes rights between spouses, traditionally husbands and wives, and their respective kin. Others see marriage as an institution that is more concerned with the legitimate affiliation of children to domestic units. The former perspective has clearly been the predominant in the study of marriage in southern Africa. This is evident in a series of excellent contributions on significance of bride-wealth exchanges (Krige and Comaroff 1981), the contestation of arranged marriages during the 1930s (Schapera 1941, Thomas 2009), the difficulties of maintaining conjugal relations in contexts of labour migration (Murray 1980), and women’s preference for staying single (Van der Vliet 1982). Hunter (2010) shows how high unemployment has undermined men’s ability to pay bride-wealth and support dependents.

Anthropologists and other scholars have paid less attention to marriage as it bears upon the status of children. Notable exceptions are Jeffreys's (1951) attempt to conceptualise lobola as child-price, and Jones' (1993) detailed account of the experiences of children residing with parents in Cape Town's municipal hostels. Studies on the status of children born out of wedlock, provide comparative insight into the nature of filial links established by marriage. Noting an increase in pre- and extra-marital pregnancies in Botswana, and Upton (2001) suggest that marriage and childbearing might well be separate domains of life. Men often prefer to marry women who have already given birth, as this guarantees their fertility. These children readily become part of the father's kin group with full rights of inheritance (also see Griffiths 1997:85). However, where no marriage occurs, the welfare of children affiliated to their mother's descent group, might well be at stake, and mothers may be compelled to negotiate for support from their fathers (Molokomme 1991:257). Moreover, Pauli (2012) shows that in Northern Namibia members of the Christian elite have begun to distinguish between children born within wedlock and 'sin children' born from extramarital 
affairs. Wives fear that such children might lay a potential claim to inheritable possessions, and that their own children might lose social and economic status.

In this article I adopt a more encompassing perspective, focusing on the broader sets of alliances created by bride-wealth (Kuper 1982). I aim to contribute to debates about marriage and children's affiliation to domestic units, by reflecting upon the issues of childcare in the context of South Africa's AIDS pandemic. Ethnographically, I draw on the results of multi-temporal fieldwork that I have conducted since 1990 among Northern Sotho and Shangaan people in Impalahoek, in the South African lowveld. [1] Formerly situated in the Lebowa Bantustan, the village is currently administered by the Bushbuckridge Municipality and Mpumalanga Province, and has a population of about 24,000 people. My analysis focuses on three different data sets. During 1991 my research assistants and I conducted a social survey of 87 of the approximately 2,000 households in Impalahoek; and during 2004, we revisited all previously surveyed households. [2] Although our samples of surveyed households for these two data sets were not random, we sought to select an equal number of households in each village section and asked standard questions about household histories, compositions and income earning. Between August and September 2014, we conducted in-depth interviews with the surviving members of 22 households containing ‘AIDS-orphans’. [3] I was first introduced to research participants by my research assistants a retired teacher and home-based care worker. During my initial visit I explained the purpose of my inquiries and obtained informed consent for their participation. On subsequent occasions I collected details of the household composition, labour force participation, and access to social grants, and listened to research participants speak on issues pertaining to marriage, kinship and childcare. Only two persons whom we approach refused to participate, largely because they were too busy to grant an extended interview. Others spoke with a great 
deal of confidence, and valued the opportunity to inform outsiders about their experiences and struggles.

As in so many other South African rural areas (see Hunter this volume, and James this volume), there has been a sharp diminution in the frequency and stability of marriage in Impalahoek. The social surveys conducted 2004 show that the percentage of married adults in sampled households declined from 64\% in 1991 to only 42\% in 2004 (Niehaus 2006:529)

[2]. Since the mid-1990s, residents of Impalahoek have had to contend with the most devastating effects of the HIV/AIDS pandemic. By 2006, sero-prevalence among pregnant women receiving antenatal care at the local Tintswalo Hospital stood at 32\% (MacPherson et al 2009:588). High incidents of HIV-infections, severe AIDS-related diseases, and numerous deaths have led to a further erosion of marriage, and have created formidable challenges in the fields of childcare.

In this article I show that on occasions AIDS-related diseases, generated blame and profound conflict between spouses, and contributed further to the erosion of marriage. However, despite the absence of the father in the lives of many children, the pandemic has not brought about a crisis of filiation. Instead, I contend that childcare arrangements have been informed by a long history of improvisations necessitated by labour migration, and also by a 'diffusion of parental obligations', which is a tenet of Northern Sotho and Shangaan kinship models. As in the case of Lesotho, the erosion of marriage has brought about a shift, if not towards matrifocality, then certainly towards care by maternal relatives (Block 2014). During illness mothers returned to their natal homes with their children, and because their fathers had not completed bridewealth payments, they could not affiliate to the patriline. Also, in Bushbuckridge, women's relative ease of access to social grants, have brought about a shift of guardianship towards female matrikin. Hence, available evidence suggest that in an 
economy marked by high unemployment and dependence upon state instituted social security systems, the marital status of parents may not be decisive to children's welfare.

\section{HIV/AIDS and Marriage}

Until the late 1950s, residents of Impalahoek lived as rent tenants, paying taxes to the South African Bantu Trust for the right to reside, keep stock, and cultivate fields. Traditionally, parents helped sons pay bride-wealth, which was set at ten cows for a Northern Sotho, and 13 cows for Shangaan brides. However, in 1958 hamlets incurred great stock losses during a most devastating epizootic. Moreover, after the implementation of agricultural betterment in 1960, and the removal of formerly scattered hamlets into concentrated village settlements, the South African Bantu Trust imposed limitations of a maximum of ten cattle per hamlet. Under these conditions, it was incumbent upon young men to pay their own bridewealth in cash.

The value of bridewealth was no longer standard, but now came to depend upon the bride’s educational qualifications. [4] Only businessmen and well-paid employees could afford to pay bridewealth in full, and instantly attain the status of husband and father. But ordinary miners and factory workers, who had manifold financial obligations, experienced the payment of bridewealth as a drawn-out process. They usually paid only an initial instalment, negotiated for the wife to take up residence in their home, and settled the outstanding debt to her parents over an extended period of time. As in the case of Lesotho that Block (2014) describes, a wife's status was profoundly liminal, and the affiliation of her children insecure.

As elsewhere in South African rural areas, marital disharmony was pervasive in Bushbuckridge. The system of oscillating labour migration, in which men were separated from their wives to work in South Africa's centres of mining and industry, was extremely 
conducive to extra-marital affairs. In addition, given the expectation of under patrilocal residence upon marriage, young wives frequently found it extremely stressful in the homes of their husband's relatives, and tensions between affines regularly culminated in accusations of witchcraft (Niehaus 2001:98-106). In 1991, a survey of 87 households showed that $64.5 \%$ of men (120 of 186) and $63.7 \%$ of women (123 of 193) above the age of twenty were married. [4] Seventy two percent of children (316 of 439) resided with, or belonged to the same household as their fathers.

Over the next two decades marriage sharply declined. De-industrialisation, as evident in the downscaling of mines and in the closure of factories, brought about drastic job, particularly among men. Whilst there were, indeed, now employment opportunities in the service sector - for taxi drivers, security guards, shop assistants and game lodge employees these did not compensate for the losses of industrial employment (Niehaus 2006). A consecutive surveys of the same 87 households showed that unemployment among economically active men increased from $16 \%$ in 1991 to $48 \%$ in 2004 . Rising unemployment had a rippling effect on domestic life and on household structures, more generally. In the context of such increased financial hardship, fewer men found it possible to pay bridewealth, secure paternity over their children, and effectively support their dependents. A survey of the same 87 households, when revisited in 2004; showed that only 48\% of men (112 of 233), and $37.5 \%$ of women (113 of 301) were married. The median age of marriage had not increased.

Increased numbers of children were now born to single mothers. Previously the father was likely to be an absent migrant labourer, who supported children financially but saw them only occasionally, during work vacations. Now the father was more likely to be absent altogether, not only in a de facto sense, but also to a de jure one. By 2004 only $50.6 \%$ of children in sampled households (251 of 496) resided in the same households as their fathers. The loss of income derived from remittances sent home by male migrants, has been offset by 
a slight increase to women’s access to secure employment, and by a considerable improvement in state instituted social security systems including non-contributory old age and disability pensions, and by child support grants (of R177 per month, introduced in 2002). These grants made an increasingly significant contribution to household income. The absence of fathers also brought increased childcare responsibilities to bear upon other household members, such as the mother's siblings and maternal grandparents (See Schatz and Ogunmefun 2007:1891).

The HIV/AIDS pandemic contributed further to existing trends pertaining to conjugal stress and to marital breakdown. A verbal autopsy survey in Agincourt, another village of Bushbuckridge, provides the clearest indication of the escalation of deaths due to AIDSrelated symptoms in the region. Until the 1995 the predominant cause of death in children were infectious diseases and malnutrition; in adolescents and young adults accidents and violent deaths; and in adults and the middle-aged, cardiovascular disease. But between 1995 and 2002, AIDS-related diseases were the most frequent cause of death in all age groups (Tolman et al. 2002). Between 1992 and 2005, life expectancy in Agincourt fell by 12 years for women and 14 years for men (Kahn et al 2007).

The discovery that a spouse had been infected with a deadly virus - in all likelihood by an extra-marital lover - has been the pretext for blame, bitter recriminations, and even, in one instance, homicide. During December 2004 the chair of a local Community Police Forum (CPF) told me of a most tragic and horrible event that occurred within the neighbourhood for which he was responsible. He said that a man called Ferris Dube (a pseudonym, like all other personal names in this article) who had returned to Impalahoek from his workplace in Johannesburg, after a long period of absence. Ferris suffered from a persistent cough and consulted a medical practitioner. His wife accompanied him and on the way back home they argued. Onlookers heard her saying that Ferris had merely returned to Impalahoek to infect 
her with the 'dreaded disease'. The next morning neighbours reported that they had heard Ferris and his wife scream at each other throughout the night, and saw smoke coming from a home. Members of the Police Forum broke down the door, but were too late. They discovered that Ferris had tied his wife to their bed with an electric cord, dosed her with petrol, and burnt her to death. He then committed suicide by also setting himself alight. Although Ferris had left a suicide note, nobody could decipher the writing. This episode was widely discussed.

But couple’s responses to HIV infections have not been uniform. Mfecane (2010) studied the problems faced by 25 HIV positive men in Bushbuckridge, who were using ARVs, in disclosing to their partners. Some decided not to disclose, in fear that their wives might desert and take away their children. Others disclosed only after their wives had promised to remain and care for them should they be HIV positive. He found that seven (41\%) of the 17 men who had disclosed were abandoned by their partners. In ten other cases the wives or partners remained, feeling obliged to support the men they loved in difficult times (Mfecane 2010:183). My research findings were roughly similar: six (46\%) of 13 HIVpositive men, and 13 (55\%) of 22 HIV positive women, reported that their spouses or partners deserted them, when the nature of their sickness became apparent. [5] In one case, a man called Joseph Khosa, who was married and worked in Gauteng, came home to his mother after he became desperately ill. During the next five years, Joseph's wife only once visited him in Impalahoek. Some HIV positive women recalled that their husbands found new wives, or went to look for work and failed to return. There were also others who wished to support their sick partners, but, because they had not paid bridewealth, were prohibited from being part of the ‘therapy management group’ (Janzen 1979).

\section{HIV/AIDS and Childcare}


The effects of conjugal disharmony, sickness, marital breakdown and parental deaths have focused attention on orphans. For example, teachers were obliged to submit regular reports to the Mpumalanga Provincial government on the exact number of orphans in local schools. In 2004, 139 out of 1,140 (12\%) learners at the Impalahoek Primary School were orphaned. 58 learners were maternal- , 66 paternal -, and 15 double orphans. These calculations approximate the results of the surveys of 89 households that I conducted in Impalahoek. From 1991 to 2004, the number of orphans increased from 47 out of 455 (10\%), to 59 out of 496 (12\%) children under the age of 18 . There seems to have been a slight increase hereafter. In 2009, estimates by the Mpumalanga government placed the total number of orphans in the Province at 18.7\% (Weckesser 2011:127).

Government policy has been based on the premise that kin and households are able to take care of children orphaned during the HIV/AIDS pandemic. This was evident during 2009, when government introduced 'foster grants' to the value of R780 per month, paid to adults recognized as legal guardians of orphans. This presupposition was born out by my observations in Bushbuckridge. During fieldwork I never encountered any street-children. Moses Khosa, a research participant who operated a small business, told me that unlike in any of the South African cities he had visited, 'it is hard to find children eating from dustbins at shopping centres [in Bushbuckridge].' It is also noteworthy that the Ekuruleni ('Safe Haven' in Tsonga) Centre for Orphans and Vulnerable Children, which catered for 153 orphaned children, only provided meals and activities until the late afternoon, when relatives came to fetch them. Shirley Ngwenya, the centre's director, told me that the Governing Board encountered stiff opposition when it planned to build sleeping quarters. 'The community argued that we should not isolate the children from their families.'

The most common arrangement was for adult relatives to act as guardians of orphaned children. The guardian was called mohlokomedi, a term that denotes someone who herds the 
cows of a relative under the mafisa cattle-loan system. Moses Khosa aptly summarised common sentiments when he remarked: 'We are a remote, but civilised area. Here it is not like the cities. Here families matter. We have aunts, uncles and other relatives. If someone dies they take over.' In contrast to guardianship, my research participants considered westernstyle adoptions of unrelated children as unnatural. They referred to the Northern Sotho saying, 'Cows do not lick other cow's calves' (Kgomo ga e latswe namane ya e ngwe) to emphasise that only kin can render proper care.

The flexible nature of Northern Sotho and Shangaan models of kinship, which posited broad, polyvalent, parental obligations by both paternal and maternal kin, accorded them with special resilience. The work of grandparents, siblings of both parents, and even maternal cross-cousins, complemented that of the mother and the father. As such paternity and maternity assumed plural rather than singular forms.

In both Northern Sotho and Shangaan models residence is virilocal. But a married couple only resides in the hamlet of the husband's parents until such time as his younger brother marries, and are then expected to set up their own independent household. Under this system the last-born son and his wife inherit the parental homestead, partly in compensation for caring for his aging parents. Both paternal and maternal grandparents (kokwane) sustain affectionate and indulgent relations with their grandchildren.

In both systems, ego calls the father's and mother's siblings of the same sex by the same term; and cross-siblings of the parents by a different term. The nomenclature of kinship also reflects pervasive elder-younger distinctions. In Northern Sotho the father is tate; his older brother ramogolo ('big father'), younger brother rangwane ('small father'), and sister rakgadi [6]. The father is, conceptually, the 'owner of the hamlet' (mong wa motse), who settles disputes, encloses and guards its borders, and represents it to the outside word. He names his children, bestows their social identity, disciplines them, and provides for their 
material needs. The father's brothers can substitute for him and, in his absence, settle dispute, provide food, and call those at fault to order. They are the first to be informed when a girl is pregnant out of wedlock or when any child is sick. The older brother (ramogolo) acts as a kind of genealogist, who informs children about their ancestors and kin. The younger brother (rangwane) negotiates bridewealth payments.

The father's sister (rakgadi), too, acts authoritatively. In ritual contexts, she is senior to her brothers, and her children senior to theirs. This is because brothers traditionally relied upon cattle from the marriages of their sisters for bridewealth, and seniority accrues to cattlegivers. The father’s sister recites the family’s praise poem during rituals, and invokes the father's ancestors (badimo) in times of distress. She advises nephews and neices on marriage, sees that all bridewealth is paid, and explains how the young wife should behave towards her in-laws. The father's siblings undertake collective responsibility for arranging the funerals of his children, should they die unexpectedly, at a young age.

Wives retained membership of their father's descent group and are still addressed by their maiden surnames. Her parents and siblings regularly visit her and sustain an active interest in the welfare of her children. The mother is called mma, her older sister mmamogolo ('big mother') younger sister mmangwane ('small mother') and her brother malome. [7] Her sisters help to bathe and feed her babies, and cradle them, behind the back. They teach her older children how to do domestic work, such as fetching water and washing clothes. The older sister (mmamogolo) is a font of wisdom about traditions. The younger sister (mangwane) teaches the girls personal hygiene, and informs them about sexual matters. She can also assist in bidewealth negotiations.

The mother's brother (malome) traditionally acts as guardian of his sister's children (Radcliffe-Brown 1952a). He arranges therapy when they are sick, disciplines them when they disobey their mother, defends them when they are accused of witchcraft, and assumes a 
leading role in arranging their funerals, should they die young. His wife (mmamalone) is obliged to assist in all these tasks. The relation between children and their maternal uncle is generally intimate, open and supportive. The boys feel comfortable enough to discuss sensitive matters, such as sex, with him. Shangaan families permit a nephew to take food from his mother's brother's home, without asking permission. In rituals the mother's brother is treated as junior to his nephew, and his wife as junior to his niece. The nephew always tastes the first fruit of the season before he does. My research assistant, who is Northern Sotho, always spoke Tsonga to his nephew, whose father was Shangaan. 'This is respect (hlonipa)', he said.

In Northern Sotho, ego calls siblings and parallel-cousins (children of the MZ or FB) of the same sex ngwanešo or warra, and siblings and parallel-cousins of the opposite sex kgaetsedi. [8] There is an expectation of intimate, close and supportive relations between siblings. Older siblings often take care of younger ones. This is evident in 'socialisation by peers' (P. Mayer and I. Mayer 1970) and in sibling guardianship. A newly married couple is often obliged to take care of a younger brother of a sibling: he pays for the sibling's education and his wife cooks and washes clothes for him or her.

The key difference in the Nothern Sotho and Shangaan kinship models pertain to cross-cousins (children of the MB or FZ). In Northern Sotho both sets of cross-cousins are called motswala (a term with no age and sex distinctions) and are permitted to have sexual intercourse and marry. Here, matital strategy aims to ensure the return of bridewealth across generations. In Tsonga, maternal cross-cousins (MBd, MBs) are called manana ('mother') and malume ('mother's brother'), and paternal cross-cousins (FZd, FZs) n'wana (son) and n'wana wa wanhwana ('daughter'). The relevance of these terms appear when read with exogamy rules. Among Shangaans cross-cousins are prohibited to have sex and marry, but young women are allowed to marry her father’s sister's husband as a second wife (Kuper 
1982). This practice cements marriage alliances (Webster 1977:193). It also posits a maternal relationship between cross-cousins.

Polyvalent kinship obligations enabled villagers to confront the formidable challenges of childcare under the system of labour migration, in which the absence of working fathers, and sometimes also mothers, was a prerequisite to children's survival. The survey of 87 households that I conducted during 1991 - well before the zenith of the HIV/AID pandemic indicated that only 41.9\% of children under 18 (191 of 455), physically resided in the same household as their mothers and fathers. 46.6\% (212) lived without their fathers, 3.3\% (15) without mothers; and 8.1\% (37) without both parents. In some situations parents dispersed their children to the homes of adult relatives, in a better position to care for them (Spiegel 1986). In others, they resided in extended households, including the remaining parent, grandparents, uncles and aunts, siblings and parallel cousins.

The diffusion of parental obligations enabled different categories of kin acted as guardians for orphans. During 1991, 21 (45\%) orphans in sampled households resided solely with their surviving parent and with uterine siblings; five (10\%) with paternal kin such as grandparents and the father's siblings; and 21 (45\%) with maternal kin, such as grandparents and the mother's siblings.

\section{Marriage and Guardianship of AIDS Orphans}

A closer analysis of ethnographic material on twenty-two households which contained orphans in Impalahoek during 2014, allows greater insight into the relationship between the marital status of (deceased) parents and the guardianship of AIDS orphans. In cases where a deceased person was married the institution of the levirate and sororate, ideally, ensured guardianship of their children by paternal kin. Where a man who had paid full bridewealth 
died, it was incumbent upon his brother to assume full conjugal and paternal responsibilities on his behalf. Where a married woman died her younger sister, or in the case of Shangaans, her sister's daughter, could assume her responsibilities as wife and mother. However, in the case an unmarried mother, her siblings should act as guardian of her children.

\section{Notwithstanding these ideals, maternal kin often assumed responsibility for childcare.}

Table 1, below, indicates who the primary guardians were of all orphans in sampled households. (28 orphans were born to 11 married mothers and 39 orphans to 13 unmarried mothers). In the category of married mothers, 9 orphans were cared for by paternal kin, 16 by maternal kin, and 3 by uterine siblings. The mother's brother played a particularly significant role. Since, he traditionally obtained bridewealth cattle from his sister for his own marriage the mother's brother was obliged to act as the guardian of her children. One research participant argued that he was a more appropriate carer than his deceased sister's widower. 'The children's father', he said, 'might remarry and his new wife will trouble the children because they are not hers.' In the cases where the deceased mother was not married, it was

Table 1: Primary guardians of AIDS Orphans in Impalahoek by the marital status of their mothers, 2014

\begin{tabular}{|l|c|c|c|}
\hline Social Relationship & $\begin{array}{l}\text { Orphans of } \\
\text { Married Mothers } \\
\text { (N11) }\end{array}$ & $\begin{array}{l}\text { Orphans of } \\
\text { Unmarried Mothers } \\
\text { (N 13) }\end{array}$ & $\begin{array}{l}\text { Sub } \\
\text { Total }\end{array}$ \\
\hline Father's Mother & 1 & 0 & 1 \\
Father's Brother & 5 & 0 & 5 \\
Father's Sister & 2 & 0 & 2 \\
Father's Cousin & 1 & 0 & 1 \\
Mother's Father & 0 & 3 & 1 \\
Mother's Mother & 6 & 13 & 19 \\
Mother's Sister & 1 & 13 & 14 \\
Mother's Brother & 9 & 0 & 9 \\
Mother's Friend & 0 & 1 & 1 \\
Siblings & 3 & 9 & 67 \\
\hline Totals & 28 & 39 & \\
\hline
\end{tabular}


predominantly the mother's mother, or mother's sister who acted as primary caretakers. Here the mother's brother played hardly any role.

Many research participants commented that the discrepancy between conceptual models that posit guardianship by paternal kin and actual financial and emotional care by maternal kin, had become greater since the 1990s. They related this to a shift from reliance upon the earnings of male migrant labourers, towards dependence on pensions and social grants allocated to women by government.

\section{Patrilineal Kin}

Paternal kin tended to act as guardians of orphans when wives resided with husbands and affines, who had sufficient social and financial resources to render continued support for her children. This was apparent during the course of 2013 and 2014, when the brothers Enos and James Shokane, both lost their wives, due to AIDS-related diseases. The two brothers were securely married and resided in an extended household with their mother (a pensioner, who had separated from their father), their brother, Samson, (a police officer, who was married and had two children), and with their sister, Doris (a single mother with two children, who was unemployed). Enos Shokane operated a relatively successful business that hired out tents for occasions such as funerals, and James had a well-remunerated position in Johannesburg. The deaths of their wives left three maternal orphans - between the ages of six and twelve years. Here the orphans' paternal kin had sufficient income to care for them, and did not wish to separate them from their grandmother, parallel, and cross-cousins. Despite occasional tensions between women of the Shokane household over issues such as household budgets in the past, they effectively suppressed all strife in the face of fatal illness and death in the household. 
In one exceptional case, Ben Mokoena asked his parallel cousin (FBs), Henry Mokoena and Henry’s first wife, Betty, to be guardians of his twelve-year old daughter, Alusia. During 2002, Ben had lost his wife, and was severely ill. When Henry visited him, Ben reportedly asked: 'Should I die, look after my child'. Henry assumed the role of guardian on the grounds that the last words of any dying person possessed innate power, and could bring severe misfortune should they be disobeyed. This arrangement was considered appropriate because Ben was not on good terms with his own family members. Henry was a fairly well-paid policeman and Betty was unable to bear her own children. Alusia assisted them with household chores and came to address Betty as 'mother' ( $m m a)$. Ben’s siblings did not object to this arrangement and his sister occasionally visited Alusia, to give her whatever support she could.

The Mother's Brother

In the wake of many broken marriages, attention focused on the mother's brother as potential guardian of his sister's children. But the mother's brother was more likely to care for children whose deceased mothers had been married at the time of their deaths. Whereas men might obtain bridewealth from the marriages of their sisters, they were unlikely to secure foster grants to care for the children of unmarried women. A social survey in the Agincourt district of Bushbuckridge, shows that during 2002 only 8 (0.4\%) of 1,886 grant applications were made by male relatives, such as fathers and uncles (Twine et al. 20007:123). Likewise, welfare bureaucrats were extremely reluctant to award such grants to the mother's brother's wife (mmamalome), whom they saw as unrelated to the orphans because she did not bear the same surname. 
Henry Mokoena and his wife, Betty, told me that in addition to caring for his paternal cousin's daughter, Alusia, they acted as guardians of his sister's four children. Henry's sister and her husband, who were next door neighbours, died in 1998 and 1999, respectively. Henry was chosen as guardian because of his status as mother's brother and relative prosperity, and also because Betty was infertile. 'I do not have my own [children]', she said, ‘Therefore I take care of others.' 'This is God's plan for me'. At the time, the oldest orphan, Robina, who was fifteen years old, and her siblings continued to reside in their mother's home. The children washed themselves, and cleaned their own rooms, but Henry paid for all necessities, and Betty cooked for them. Eventually, the household managed to secure a disability grant for the youngest child, who was a deaf mute. But the grant was paid directly to Robina, as his oldest sister. Betty alleged that Robina sometimes misused the grant, and complained that she had to work on a nearby fruit farm to earn additional money to care for the orphans.

I heard endless complaints by orphans that their mother's brothers failed to render proper support. Mary Mogale recalled that after the death of her unmarried mother and grandmother in 2007, she and her sister- who were in their mid-teens - continued to reside in their home. They had three maternal uncles: a medical doctor in Nelspruit (who was married with three children), a boilermaker in Johannesburg, and a construction worker in Machadodorp (who were both single). The boilermaker regularly deposited money into their bank account, sometimes up to R1,000, but he ceased to do so, once he too had married and had his own children.

Mary blamed the wives of her maternal uncle. 'He will say, “My wife does not allow me to take care of my sister's children”'. It was not only the inability to access social welfare that made wives reluctant to care for children of her husband's sister. Traditionally, I was told, the relationship between a man's wife and sister was tense. Because a man used cattle from his sister's marriage as bride-wealth, his sister claimed seniority over his wife, and her 
children claimed entitlement to greater privileges than their cousins. These claims undermined the vitally important principle of equivalence between siblings. In the case of Northern Sotho households, there was the additional recognition and fear that foster children were entitled to have sex with, and even to marry, his biological children. This concern was particularly acute when orphans were poor, and were suspected of having inherited a potentially deadly virus from their deceased parents.

The Mother's Sisters

\section{As the mother's bother has become less able to provide financial care, the mother's sister has} increasingly assumed this responsibility. In terms of conceptual models of kinship, the maternal aunt appears to be an ideal guardian. In the levirate, she substitutes for her sister. She also assumed pedagogical responsibilities towards her nephews and nieces. Moreover, several research participants expressed the opinion that the mothers' sister's husband was more likely to accept affinally-linked orphans into his home, than the mother's brother's wife.' A woman is not linked to her sister's husband by bridewealth, and has no authority in his home. Moreover, the children of sisters are classificatory siblings: none are entitled to special privileges, and sexual intercourse between them is perceived to be incestuous. The prominence of the mother's sister is also an index of the feminization of childcare, and of her greater chances of being registered as legal guardian by the welfare bureaucracy, than her brother's wife.

Pitso Mashile found her mother’s sister and her husband to be far more accommodating than her mother's brother and his wife. After her mother had died in the village, Wendover, her grandmother and sisters moved to Impalahoek. But Pitso remained in 
Wendover because she was in her final year of high school and could not secure a transfer to any school in Impalahoek. Pitso thus moved to the home of her mother's younger sister.

'My mother's sister [mangwane] was kind and asked me to stay with them. If she saw a child she would say, “This is my child also.” Her husband did not object. He was not working, but said "Come and stay here! You are also our child! We will share everything!’

It is nonetheless significant that most guardians of their sister's children were single. Jane Ndlovu, who was a divorcee, said that because she wanted to be in control of her own household, she had no desire to remarry. Thus, she did not feel under any constraint when she decided to accommodate her deceased sister's son, who experienced profound conflict with his brother, and did not wish to stay with his grandmother. Jane found his presence around the home comforting, because, in recent years her neighbourhood had become invested with violent crime. Other guardians commended mature girls who rendered a helping hand around the home by fetching water, collecting firewood, cooking maize porridge and cleaning.

The mother's sister was more likely than the mother's brother to secure access to foster grants. The process of application was, nonetheless, fraught with uncertainties. Denise Monareng filled in 'change of custody' forms for two of her deceased sister’s four children, who were under the age of eighteen. After three months, government officials told her that the forms had been 'lost in the system' and asked her to fill in new ones. Another three months later, she received two grants - valued at R310 each. But according to Denise, the grants were of insufficient value to support the children's needs: she remarked that a single school uniform for one child cost R459. Mary Mkhansi and her siblings filled in forms to apply for maintenance and foster grants for their deceased sister's six children. But the outcome was unsuccessful. The social workers told her that the children's biological fathers, who were still alive, were responsible for supporting them financially. Mary said that she had no knowledge of their whereabouts. Unlike the mother's brother, the mother's sister found it 
exceptionally difficult to discipline orphaned children. Maria Nonyane complained that Albert Mola, the orphaned son of her younger sister, bullied other children in the neighbourhood, dropped out of primary school in 2013, and spent his days at a shopping centre, earning small amounts of cash by carrying groceries for customers. Maria feared that he had become a member of criminal gangs that roamed about the village at night.

\section{Mother's Mother}

The maternal grandmother (kokwane), too, had become a prominent guardian. Grandparents were virtually the last AIDS-free generation, and grandmothers felt a deep sense of filial responsibility towards their grandchildren (Block 2014). Under the system of labour migration, elderly women often cared for the children of their married sons, and single daughters, working wage earners in South Africa’s industrial centres. However, in the case of parental death the mother's mother was seen, not as a substitute for her daughter, but rather as a last resort, in the absence of alternative arrangements.

From the viewpoint of orphaned children, the mother's mother was frequently a preferred guardian. Fortes (1949:236-240) and Radcliffe-Brown (1952b:96-97) observe that whilst interactions between proximate relations in different African contexts are characterized by hierarchy and formality, those between alternate generations allow for greater equality and even intimacy. This is especially true for maternal grandparents, linked to grandchildren as receivers of bridewealth from the marriages of their mothers. This contrast is borne out by the experienced of Tembisa Ubisi. Tembisa’s parents divorced in 1987, when he was merely one year old, and for the next twelve years he lived with his mother and stepfather. But his stepfather died in 1999, and his mother in 2002, both from AIDS-related diseases. Hereafter, Tembisa lived briefly with his father, but soon experienced conflict. 'We had to sleep in the 
same bed and I wanted to be free. I had a private life and I had nowhere to be with my girlfriends.' Tembisa said that his father was regularly drunk, swore at him, and spread unfounded rumours that he had impregnated many young women. Tembisa eventually went to live with his maternal grandmother. He found this arrangement more convenient. In her house he had his own room, and unlike his father, she tolerated his love affairs.

All grandmothers who were above the age of 60 years had access to state pensions valued at R1, 390 in 2014 - a most valuable form of household income. Pensions had important redistributive effects. In Bushbuckridge, women were more inclined than men to spend their money on resources such as food, and actually saw their pensions as intended as a subsidy for the entire household (Schatz and Ogunmefun 2007:1394). This is linked to the perception that care work is women's burden, and that it is incumbent upon grandmothers to demonstrate love towards their grandchildren in both sentimental and material terms (Weckesser 2011:40,91). As legal guardian grandmothers could also access foster grants on behalf of their grandchildren. Large multi-generational households, containing the mother's mother, were almost completely welfare dependent. Bayeforile Mapayile, an 80-year-old woman, was shaken by the successive deaths of her husband, her son, married daughter, and unmarried daughter, who suffered from AIDS-related diseases. In 2014, she lived with her unmarried son, eight grandchildren (including six orphans), and three great-grandchildren. The household relied upon Bayeforile’s pension, the wages of her son and oldest granddaughter, who worked at a nearby shopping centre, the foster grant of one grandson, and maintenance grants of three great-grandchildren. The household barely made ends meet, and were obliged to visit the magistrate each three months so that he could confirm that their conditions remained unchanged.

Maternal grandmothers, nonetheless, operated under a great deal of pressure, being burdened with having to care for young dependents in the twilight of their lives, often 
through no choice of their own. As such they were unable to see care as an investment, older children could reciprocate (Weckesser 2011:95). Flora Ndlovu, who was 75 years old, cared for five grandchildren (of whom two were orphans), and two great-grandchildren. She told me that as a mother she, herself, had to raise her own children, by selling home-brewed beer to men in the compounds. She had no chance to go to school and did not receive any child maintenance grants. Today she still looked after her grandchildren, wash them and prepare their lunch boxes before they go to school. This task, she said, is not for the faint-hearted. 'I have no help and I am worn out.’

\section{Siblings}

Many orphans resided in households that contained no members of ascending generations. Such households might well be described as 'child headed' and viewed as an index of desperation, arising from the failure of kinship to render social care (Sharp and Spiegel 1985). But, here the failure of care cannot be generalized to all kinship relations. Where adults proved unreliable, orphans turned to older siblings for assistance. The resilience of this relationship does not merely pertain to the structural ‘equivalence of siblings’ (RadcliffeBrown 1950). During the history of labour migration, uterine siblings often developed mutually supportive bonds, independent of those to their parents (Niehaus 1994).

On some occasions, siblings collectively inherited and managed the homestead of their deceased parents. In 2001, Prudence Mnisi told me that both her parents died in hospital. At the time she, a single mother aged twenty-five, was obliged to care for five younger siblings. Prudence’s grandparents were resident on a white-owned commercial farm, and only occasionally sent them maize meal. Her paternal aunt, who lived in a village nearby, was on bad terms with their parents, and their maternal kin were not prepared to help. Prudence 
secured food parcels for the household and, with the help of the local school principal, filled in applications for foster grants for her three younger siblings, and also for child maintenance grants for her two sons. (She was awarded these after two years.) Prudence also took up employment at a fruit farm. 'Our situation was very pathetic'. 'We sometimes begged neighbours for food and we went to sleep on empty stomachs. But it was better when the food parcels came.’ But Prudence said that her younger siblings understood their situation.

'Later our father's sister [rakgadi] offered to be guardian for one of the children. But we - the children - declined her offer. We wanted to stay together. We did not understand what her aim was. She might have been after money. It was very important for us to remain together.'

By 2014, three Mnisi siblings had married and left home, and the two sisters who remained with Prudence, were both securely employed at game lodges. She had clearly distinguished herself as a capable guardian.

\section{Conclusions}

In South Africa public fears that the rise in unmarried mothers and the HIV/AIDS pandemic might generate crisis of orphans without adult case, accompanied by a rising tide of disorder and criminality (Bray 2003), have not been realised. Experiences from the village of Impalahoek provide some insight into why this should be so.

To summarise, in this article I sought to contribute to ongoing debates about marriage and the position of children by investigating marriage and childcare in the aftermath of South Africa’s devastating HIV/AIDS pandemic. In Impalahoek, the pandemic occurred alongside a rising tide of unemployment, and contributed further to the erosion of conjugal bonds. In a substantial number of cases men and women deserted spouses infected with HIV when the nature of their sickness became apparent. HIV/AIDS also contributed to a significant increase 
in the number of orphans throughout the village. Whilst marriage does provide for the affiliation of children to the father's descent group, I observed that the breakdown of marriage has not led to a crisis of orphans who are unaffiliated to domestic groups.

In Impalahoek the marital status of parents might not be decisive in the welfare of children and orphans. As we have seen orphans of unmarried mothers were not significantly disadvantaged in relation to those of married mothers, in securing access to care. The flexible nature of Northern Sotho and Shangaan kinship systems, marked by a diffusion of parental obligations, have facilitated the guardianship of orphans by adults who are not necessarily their progenitors. Maternal kin - such as the mother's siblings and parents - and also the older siblings of children, have increasingly become more inclined to provide financial and emotional care for orphans than relatives of their fathers. In some cases marriage might actually impede care for children who are not direct offspring. This is apparent in the reluctance of the wives of mother's brothers, and to a lesser extent of father's brothers, to render care for orphaned children, related through them purely through marriage. We can explain this shift by high male unemployment in the context of industrial decentralisation, but also by the greater capacity of female relatives of orphans to navigate the South African social security system to secure access to child maintenance and foster grants.

\section{Acknowledgements}

I acknowledge the help of Eliazaar Mohlala, a retired teacher, and of Jane Ndlovu, a homebased care worker, who acted as fieldwork assistants, and of all research participants. Erdmute Alber, Florence Bernault, Adam Kuper, and Jacqueline Solway made valuable comments and suggestions on an earlier draft of this paper.

\section{Notes}

1.Throughout the article I use pseudonyms to denote the village of fieldwork and all personal names. I do so to protect the anonymity of my research participants. Unless specified 
otherwise, all vernacular words and expressions are in the Sepulana dialect of Northern Sotho.

2. In Impalahoek, the household generally correlates to those living on the same residential stand. Members of all the original households that we visited during 1990, still resided on the same stands, when we visited them during 2004. In the thirteen years between our visits, numerous persons had died, or migrated to new residential stands. But there was, generally, an increase in household sizes. In times of financial hardship, siblings born to the same mother often resided in separate homesteads on the same residential stand.

3. None of the members of the 22 households we interviewed during 2014 formed part of the previously sampled households.

3. Stadler (1994) conducted an in-depth survey of bridewealth payments in a nearby village, also in Bushbuckridge. He found that in 26 recorded marriages, that occurred during the 1980s and early 1990s, the amount of bridewealth varied from R120, for a young woman with no formal schooling, to R12,000 for a bride with a nursing diploma.

4. The disjunction in the figures of married men and women is explained by the presence in a few exceptional cases of polygyny.

5. Two male and ten female research participants were not married, and did not have sexual partners during the time of sickness.

6. The corresponding Tsonga terms are tatana (father), bavankulu (father's older brother), bavantsongo (father's younger brother), hahani (father's sister).

7. The corresponding Tsonga terms are manana (mother) mahaninkulu (mother's older sister), mahanintsongo (mother's younger sister) and malume (mother’s brother).

8. This differs from Tsonga, in which ego calls brothers and male parallel cousins buti, but sisters and female parallel cousins tate.

\section{References}

Block, E. 2014. 'Flexible Kinship: Caring for AIDS orphans in rural Lesotho’. Journal of the Royal Anthropological Institute 20 (4), 711-727.

Bray, R. 2003. 'Predicting Social Consequences of Orphanhood in South Africa'. African Journal of AIDS Research 2 (1), 39-55.

Fortes, M. 1949. The Web of Kinship among the Tallensi. London: Oxford University Press.

Griffiths, A. 1997. In the Shadow of Marriage: Gender and Justice in an African Community.

Chicago Il: University of Chicago Press. 
Janzen, J. 1978. The Quest for Therapy: Medical Pluralism in Lower Zaire. Berkeley CA; University of California Press.

Jeffreys, M.D.W. 1951. Lobola as child price. African Studies 10 (4), 145-184.

Jones, S. 1993. Assaulting Childhood: Children's Experiences of Migrancy and Hostel Life in South Africa. Johannesburg: Wits University Press.

Hunter, M. 2010. Love in the Time of AIDS: Inequality, Gender and Rights in South Africa. Bloomington: Indiana University Press.

Kahn, KM, M. Garenne, M. Collinson, and S. Tollman. 2007. 'Mortality Rates in the New South Africa: Hard to make a Fresh Start’. Scandinavian Journal of Public Health 35 (69), 29-34.

Krige, E. and J. Comaroff. eds. 1981. Essays on African Marriage in Southern Africa. Juta: Cape Town.

Kuper, A, 1982. Wives for Cattle: Bridewealth and Marriage in Southern Africa. London: Routledge and Kegan Paul.

Leach, E. 1982. Social Anthropology. Fontana.

MacPherson, P. M. Moshabela, N. Martinson and P. Pronyk. 2009.’Mortality and Loss to Follow Up among HAART indicators in rural South Africa.' Transactions of the Royal Society for Tropical Medicine and Hygiene 103: 588-593.

Mfecane, S. 2010. Exploring Masculinities in the Context of ARV Use: A Study of Men Living with HIV in a South African Village. Unpublished PhD thesis. Johannesburg WISER: University of the Witwatersrand.

Molokomme. A. 1991. "Children of the Fence": The Maintenance of Extra-marital children under law and practice in Botswana. Leiden: African Studies Centre.

Murray, C. 1981. Families Divided: The Impact of Migrant Labour in Lesotho. Cambridge: Cambridge University Press. 
Niehaus, I. 1994. 'Disharmonious spouses and harmonious siblings: Conceptualising

Household Formation among urban residents in Qwaqwa.' African Studies 53 (1), 115135.

2006. 'Doing Politics in Bushbuckridge: Work, Welfare and the South African Elections of 2004.' Africa 76 (4), 521-548.

Niehaus, I. with E. Mohlala and K. Shokane. 2001. Witchcraft, Power and Politics: Exploring the Occult in the South African Lowveld. London: Pluto.

Pauli, J. 2012.'Creating Illegitimacy: Negotiating Relations and Reproduction within Christian Contexts in Northwest Namibia.' Journal of Religion in Africa 42 (2), 408432.

Radcliffe-Brown, A.R. 1952a (1924). 'The Mother’s Brother in South Africa’. In Structure and Function in Primitive Society. London: Cohen and West, 15-32, 1952b (1940). 'On joking relationships'. In Structure and Function in Primitive Society. London: Cohen and West, 90-104.

Schatz, E and C. Ogunmefun.2007. 'Caring and Contributing: The Role of Older Women in Rural South African multi-generational Households with AIDS. World Development 35 (8), 1390-1403.

Schapera, I. 1941. Married Life in an African Tribe. New York: The Sheridan House Sharp, J. and A. Spiegel. 1985. 'Vulnerability to impoverishment in South African rural areas: the erosion of kinship and neighbourhood as a social resources.' Africa 55 (2), 133-152.

Stadler, J. 1994. Generational Relationships in a Lowveld Village: Questions of Age, Household and Tradition. Unpublished MA dissertation. (University of the Witwatersrand: Department of Social Anthropology). 
Tollman, S, K. Kahn, K. Herbst, M. Garenne and J. Gear. 1999. Reversal in Mortality Trends: Evidence from the Agincourt filed site, South Africa. AIDS 13, 1091-1097. Thomas, L. 2009. 'Love, Sex, and the Modern Girl in 1930s Southern Africa.’ In J. Cole and L. Thomas, (eds.) Love in Africa, Chicago: University of Chicago Press, 31-57.

Twine, R., M. Collinson, T. Polzer and K. Kahn. 2007. 'Evaluating access to a child-oriented poverty alleviation intervention in rural South Africa.' Scandinavian Journal of Public Health 35(69): 118-127

Upton, R. 2001. ““Infertility Makes Your Invisible”: Gender, Health and the Negotiation of Fertility in Northern Botswana.' Journal of Southern African Studies 27 (2), 349-362. Van der Vliet, V.1984. 'Staying Single: A Strategy against Poverty?’ Carnegie Conference Paper 116. Cape Town: SALDRU.

Webster, D. 1977. 'Spreading the risk: The principle of Laterality among the Chopi’ Africa 47 (2), 192-207.

Weckesser, A. 2011. Girls, Gifts and Gender: An ethnography of the Materiality of Care in Rural Mpumalanga, South Africa. PhD thesis. University of Warwick: School of Health and Social Studies. 